\title{
HUBUNGAN ANTARA KEBIASAAN MEROKOK DENGAN KADAR KARBON MONOKSIDA (CO) PEROKOK
}

\author{
Risa Apriani Hilyah*, Fetri Lestari, Lanny Mulqie \\ Program Studi Farmasi, Fakultas Matematika dan IImu Pengetahuan Alam, Universitas Islam Bandung \\ Jl. Rangga Gading No. 8, Bandung 40116, Indonesia
}

Info Article

Submitted :

11 September 2020

Revised:

7 November 2020

Accepted :

14 November 2020

\section{Corresponding Author :}

Risa Apriani Hilyah

\section{Email :}

risaapriani1329@gmail.com

\section{ABSTRAK}

Kebiasaan merokok merupakan salah satu gaya hidup yang dapat menimbulkan masalah kesehatan terutama penyakit kardiovaskular karena rokok mengandung bahan kimia beracun, salah satu diantaranya adalah gas CO. CO yang terhirup akan berikatan dengan hemoglobin sehingga kemampuan darah dalam mensuplai $\mathrm{O} 2$ ke jaringan menjadi berkurang. Pengukuran kadar CO menggunakan smokerlyzer menjadi metode alternatif untuk pendeteksian dini gangguan kesehatan akibat rokok. Penelitian ini bertujuan untuk mengetahui hubungan antara kebiasaan merokok dengan kadar CO perokok di wilayah Puskesmas Antapani Kota Bandung. Penelitian bersifat observasional dengan desain case control study yang dilakukan di wilayah Puskesmas Antapani Kota Bandung. Sampel penelitian berjumlah 10 orang perokok yang diambil secara convenience sampling. Pengukuran kadar CO dilakukan dengan menggunakan smokerlyzer. Hasil penelitian menunjukan bahwa terdapat hubungan antara kebiasaan merokok dengan kadar CO perokok di wilayah Puskesmas Antapani Kota Bandung. Jumlah rokok perhari dan lama merokok memiliki korelasi bermakna dengan kadar CO dengan nilai $r=0.698$ ) dan $(r=0.755)$.

Kata kunci: kebiasaan merokok, kadar CO

Access this article

回䄈回

Qin

ipis:

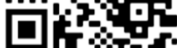

SCAN ME
ABSTRACT

Smoking is one of habits that can cause much more health problems than cardiovascular disease because in every cigarette contain toxic chemicals, one of them CO. The inhaled carbon monoxide will be bound to the haemoglobin in blood reducing its ability to transport $\mathrm{O} 2$ to body tissues. $\mathrm{CO}$ measurement using smokerlyzer is an alternative method for early detection of a health disorder caused by smoking. This study aims to find out the correlation between smoking habits and $\mathrm{CO}$ levels of in a district in the city of Bandung. The study is a observasional research in design of case control study in Antapani Public Health Centre Bandung City. The samples were taken from 10 people using convenience sampling technique. The measurement of $\mathrm{CO}$ levels was done using smokerlyzer. The result shows that there is a correlation beetwen smoking habits and $\mathrm{CO}$ levels of smokers study in Antapani Public Health Centre Bandung City. The number of 
cigarettes a day and along time smoking is correlated with a meaningful CO levels $r=0.698)$ and $(r=0.755)$.

Keywords: smoking habit, CO levels

\section{PENDAHULUAN}

Kebiasaan merokok oleh sebagian besar masyarakat indonesia telah menjadi kebutuhan yang tidak bisa ditinggalkan, meskipun bahaya dari rokok telah diketahui dapat menimbulkan masalah kesehatan. Menurut Riskesdas tahun 2018 prevalensi perokok di Jawa Barat adalah sebesar 27,1\% perokok setiap hari dan 4,9\% perokok kadang-kadang (Kementerian Kesehatan RI, 2018). Menurut Depkes Jabar 2016 tercatat 29,9\% penduduk Kota Bandung merupakan perokok aktif (Inayatillah dkk, 2014).

Bahaya rokok bagi kesehatan disebabkan karena terdapat 7000 bahan kimia yang terkandung dalam setiap bantang rokok dan diantaranya bersifat toksik, salah satunya adalah gas CO (Hanum \& Wibowo, 2016). CO yang terhirup kedalam tubuh melalui saluran pernafasan akan berikatan dengan hemoglobin membentuk $\mathrm{HbCO}$. Adanya $\mathrm{HbCO}$ ini menyebabkan kemampuan darah untuk mentransport $\mathrm{O} 2$ ke jaringan tubuh berkurang. Akibatnya suplai $\mathrm{O} 2$ dalam jaringan-jaringan dan sel-sel tubuh menurun, sehingga semakin tinggi konsentrasi $\mathrm{HbCO}$ dalam darah kemungkinan terjadinya gangguan kesehatan semakin meningkat (Dewanti, 2018).

Pemerintah Indonesia mulai tahun 2009 telah menjalankan program pengendalian dampak merokok bagi kesehatan yaitu dukungan untuk berhenti merokokyang secara teknis dilakukan fasilitas pelayanan kesehatan milik Pemerintah dan pemerintah daerah (Menteri Kesehatan RI, 2013). Salah satu upaya pendeteksian dini dan pencegahan terjadinya resiko gangguan kesehatan akibat rokok yaitu dilakukan pengukuran kadar CO menggunakan CO portable smokerlyzer.

Menurut penelitian Inayatillah (2014) terdapat hubungan yang bermakna antara kebiasaan merokok dengan kadar CO (Inayatillah dkk, 2014). Tujuan dari penelitian ini adalah mengetahui hubungan antara kebiasaan merokok dengan kadar CO perokok di wilayah Puskesmas Antapani. Manfaat penelitian ini diharapkan dapat menjadi landasan data kondisi fisiologis perokok dan menstimulasi program berhenti merokok di wilayah Puskesmas Antapani.

\section{METODE PENELITIAN}

Penelitian ini merupakan penelitian observasional dengan desain case control study yang dilakukan pada bulan Maret 2020 di di wilayah Puskesmas Antapani. Sampel penelitian berjumlah 10 orang perokok yang berada di wilayah Puskesmas Antapani. yang telah mengisi dan menandatangani informed consent form. Teknik pengambilan sampel dilakukan berdasarkan convenience sampling. Pengumpulan data primer dilakukan melalui pengukuran kadar CO dilakukan dengan menggunakan smokerlyzer. Analisis statistik untuk melihat hubungan kebiasaan merokok dengan 
kadar CO digunakan uji korelasi Rank

Spearman.

\section{HASIL DAN PEMBAHASAN}

Tabel 1. Kebiasaan merokok pada kelompok perokok

\begin{tabular}{lc}
\hline \multicolumn{1}{c}{ Variabel } & Perokok $(\mathbf{n}=\mathbf{1 0})$ \\
\hline Jumlah rokok perhari & \\
$1-10$ batang & $8(80 \%)$ \\
$11-20$ batang & $1(10 \%)$ \\
$>20$ batang & $1(10 \%)$ \\
Lama merokok & \\
$1-10$ tahun & $4(40 \%)$ \\
$11-20$ tahun & $3(30 \%)$ \\
$>20$ tahun & $3(30 \%)$ \\
\hline
\end{tabular}

Berdasarkan Tabel 1. rata-rata jumlah rokok yang dihisap setiap hari oleh perokok di wilayah Puskesmas Antapani adalah 1-10 batang sebesar $80 \%$ dan $10 \%$ yang menghisap rokok sebanyak 11-20 dan $>20$ batang perhari. Kemudian sebesar $40 \%$ responden telah merokok selama 1-10 tahun. Sementara yang telah merokok selama 11-20 tahun dan $>20$ tahun masing-masing sebesar 30\%. Banyaknya jumlah rokok yang dihisap perhari dan lama merokok disebabkan adanya kandungan nikotin. Sesuai dengan teori yang menyatakan bahwa nikotin menimbulkan efek adiksi atau ketergantungan sehingga biasanya perokok meningkatkan atau menambah jumlah rokok yang dihisap setiap harinya (Benowitz, 2010). Selain itu nikotin dapat menyebabkan para perokok tidak dapat berhenti untuk merokok dan akan merokok terus menerus sampai puluhan tahun lamanya karena sudah menjadi suatu kebiasaan dan kebutuhan (Amelia dkk, 2016).

Tabel 2. Rata-rata kadar CO perokok

\begin{tabular}{ccc}
\hline \multirow{2}{*}{ Variabel } & \multicolumn{2}{c}{ Perokok $(\mathbf{n}=\mathbf{1 0})$} \\
\cline { 2 - 3 } & Laki-laki $(\mathbf{n}=7)$ & Perempuan $(\mathbf{n}=\mathbf{3})$ \\
\hline Kadar CO (ppm) & $16,14 \pm 1,95 \#$ & $10,33 \pm 0,58 \#$ \\
\hline \multicolumn{2}{l}{ Keterangan: \#: rerata \pm standar deviasi }
\end{tabular}.

Berdasarkan Tabel 2. rata-rata kadar CO perokok laki -laki lebih tinggi dibandingkan perempuan yaitu sebesar 16,14 ppm, sedangkan perokok perempuan 10,33 ppm. Hasil ini sesuai dengan rekomendasi dari PDPI (Perhimpunan Dokter Paru Indonesia) yang menyatakan bahwa untuk kriteria perokok kadar CO $\geq 10$ ppm (Inayatillah dkk, 2014). Peningkatan kadar CO pada 
perokok disebabkan karena gas CO yang berasal dari asap rokok yang dihirup menyebabkan CO berikatan dengan hemoglobin untuk membentuk $\mathrm{HbCO}$ (Andersson \& Møller, 2010).

Peningkatan kadar CO dalam darah beresiko menyebabkan terjadinya penurunan suplai $\mathrm{O} 2$ ke jaringan, terutama ke otak dan jantung. Ketika kadar CO meningkat maka suplai $\mathrm{O} 2$ ke jantung akan menurun sehingga terjadi peningkatan denyut jantung, sesak nafas dan memicu terjadinya penyakit jantung koroner. Resiko lain yang dapat timbul akibat tingginya kadar CO dalam darah diantaranya sakit kepala, pusing, mual, bahkan dapat menyebabkan koma, kejang dan kematian (Dewanti, 2018).

Tabel 3. Hubungan kadar CO dengan kebiasaan merokok pada perokok

\begin{tabular}{lcc}
\hline \multirow{2}{*}{ Variabel } & \multicolumn{2}{c}{ Kadar CO (ppm) } \\
\cline { 2 - 3 } & Nilai -p & Nilai korelasi \\
\hline Jumlah rokok per hari & 0.025 & $0.698^{*}$ \\
Lama merokok & 0.012 & $0.755^{*}$ \\
\hline
\end{tabular}

Keterangan: Nilai -p dihitung menggunakan Uji Rank Spearman, $\left(^{*}\right)=$ korelasi bernilai signifikan pada angka signifikansi 0,05

Eliminasi CO terjadi melalui paruparu dan memiliki waktu paruh 5-6 jam pada suhu tubuh dan akan tetap ada dalam darah sekitar 8 jam (Goldstein et al., 2018). Maka dari itu pada penelitian ini ketika melakukan pengukuran kadar CO pada perokok waktu terakhir kali merokok dipastikan $\leq 8$ jam agar tidak terjadi kesalahan dalam penafsiran hasil. Berdasarkan Tabel 3. terdapat hubungan yang bermakana antara jumlah rokok yang dihisap perhari dengan kadar CO dengan kekuatan korelasi kuat $(r=0.698)$. Hasil pada penelitian ini sejalan dengan penelitian Putri (2018) yang menemukan korelasi yang bermakna antara jumlah rokok yang dihisap dengan kadar CO (Putri, 2018).

Jumlah rokok yang dihisap perhari dapat mempengaruhi kadar CO ekspirasi pada perokok dengan perkiraan bila merokok 20 batang rokok/hari maka kadar CO akan meningkatkan kadar CO sebesar
15-34 ppm, bila merokok 40 batang/hari akan meningkat menjadi 25-60 ppm (Inayatillah dkk, 2014). Terdapat hubungan yang bermakna antara lama merokok dengan kadar CO pada perokok dengan kekuatan korelasi sangat kuat $(r=0.755)$. Hasil pada penelitian ini sejalan dengan penelitian Kumar et al (2010) yang menyatakan adanya korelasi yang bermakna antara lama merokok dengan kadar CO ( $p<0,001$; $r=0,550)$ (Kumar et al, 2010). Semakin lama merokok maka semakin lama terpapar CO dari asap rokok dan jumlah asap rokok yang dihirup menjadi lebih banyak sehingga kadar CO akan menjadi lebih meningkat. Hal ini karena sifat $\mathrm{HbCO}$ yang lebih stabil dibandingkan $\mathrm{HbO}$ (Wimpy \& Harningsih, 2020).

\section{KESIMPULAN}

Berdasarkan penelitian yang telah dilakukan dapat disimpulkan bahwa terdapat hubungan antara kebiasaan 
merokok dengan kadar CO perokok di wilayah Puskesmas Antapani. Jumlah rokok perhari dan lama merokok memiliki korelasi bermakna dengan kadar CO dengan nilai $(r=0.698)$ dan $(r=0.755)$.

\section{UCAPAN TERIMA KASIH}

Penulis mengucapkan terimakasih kepada pihak Puskesmas Antapani yang telah menyediakan fasilitas alat ukur smokerlyzer, D-piece dan steribreath mouthpieces sehingga penelitian ini berlajan dengan lancar.

\section{DAFTAR PUSTAKA}

Amelia R, Nasrul E dan Basyar M., 2016. Hubungan Derajat Merokok Berdasarkan Indeks Brinkman dengan Kadar Hemoglobin, Jurnal Kesehatan Andalas, 5(3): 619-624.

Andersson MF dan Møller AM., 2010. Assessment of carbon monoxide values in smokers: A comparison of carbon monoxide in expired air and carboxyhaemoglobin in arterial blood, European Journal of Anaesthesiology, 27(9): 812-818.

Benowitz NL., 2010. Nicotine addiction, New England Journal of Medicine, 362(24): 2295.

Dewanti IR., 2018. Identification of CO Exposure, Habits, $\mathrm{COHb}$ Blood and Worker's Health Complaints on Basement Waterplace Apartment Surabaya, Jurnal Kesehatan Lingkungan, 10(1): 59.

Goldstein AO., Gans SP., Ripley MC., Kotsen C dan Bars M., 2018. Use of Expired Air Carbon Monoxide Testing in Clinical Tobacco Treatment Settings, Chest, 153(2): 554-562.

Hanum H dan Wibowo A., 2016. Pengaruh Paparan Asap Rokok Lingkungan Pada Ibu Hamil Terhadap Kejadian Berat Bayi Lahir Rendah, Majorty, 5(5): 2.

Inayatillah IR., Syahrudin E \& Susanto AD., 2014. Kadar Karbon Monoksida Udara Ekspirasi pada Perokok dan Bukan Perokok serta Faktor-Faktor yang Mempengaruhi, Jurnal Respirologi Indonesia, 34(4): 180190.

Kementerian Kesehatan Rl., 2018. Riset Kesehatan Dasar Tahun 2018, Badan Penelitian dan Pengembangan Kementerian Kesehatan Republik Indonesia, Jakarta: 124.

Kumar R., Prakash S., Kushwah AS dan Vijayan VK., 2010. Breath carbon monoxide concentration in cigarette and bidi smokers in India, The Indian Journal of Chest Diseases \& Allied Sciences, 52(1): 1924.

Menteri Kesehatan RI., 2013. Peraturan Menteri Kesehatan Republik Indonesia Nomor 40 Tahun 2013 tentang Peta Jalan Pengendalian Dampak Konsumsi Rokok Bagi Kesehatan, Menkes RI, Jakarta: 13.

Putri ME., 2018. Korelasi Jumlah Batang Rokok Dengan Kadar Co Pada Remaja Perokok Di Smk Kota Jambi, Jurnal Akademika Baiturrahim Jambi, 7(2): 123.

Wimpy dan Harningsih T., 2020. Pengaruh lama penggunaan rokok elektronik terhadap kadar karboksihemoglobin pada perokok elektronik, Jurnal Farmatesis, 9(1), 41-50. 